\title{
Anthropometric Characteristics of Olympic Female and Male Artistic Gymnasts from 1996 to 2016
}

\author{
Características Antropométricas de Gimnastas Artísticos \\ Olímpicos Femeninos y Masculinos de 1996 a 2016
}

Atikovic, A.

ATIKOVIC, A. Anthropometric characteristics of olympic female and male artistic gymnasts from 1996 to 2016. Int. J. Morphol., 38(4):990-996, 2020.

SUMMARY: Success in artistic gymnastics certainly depends on the morphological characteristics of the athletes, some of which are basic body height and weight. The aim of this study is to determine whether there is a statistically significant difference in body height and weight between the male and female participants on the Olympic Games from 1996 to 2016. The following variables were chosen: body weight $(\mathrm{kg})$, body height $(\mathrm{cm})$. The results did show significant differences between women's artistic gymnastics in body weight and height over a 20-year period. In men's artistic gymnastics we didn't find the difference. This research is important in setting comparative parameters in the selection process and sport specialization regarding morphological characteristics according to different events of gymnasts at the elite level.

KEY WORDS: Artistic Gymnastics; Olympic Games; Elite Athletes; Anthropological Characteristic.

\section{INTRODUCTION}

Gymnastics events have been contested at every Summer Olympic Games since the birth of the modern Olympic movement at the 1896 Summer Olympics in Athens. The Olympic Games (OG) brings together the best gymnasts in the world. Most forms of competitive gymnastics events are ruled by the Fédération Internationale de Gymnastique (FIG) (The Fédération Internationale de Gymnastique, 2013). Artistic Gymnastics is usually divided into Men's (MAG) and Women's (WAG) Gymnastics. Men compete on six apparatus and women compete on four apparatus. Currently, in the Olympics or World Championships competition, the meet is divided into several sessions that are held on different days: qualification (C-I), all-around finals (C-II), team finals (C-III) and event finals (C-IV).

Studying the changes in anthropometric measurements of the Olympic all-around gymnastics champions can demonstrate how the size and shape of the athletes have changed over time. Gymnasts have usually always been little, because it provides a plus of higher balance and easier rotation in the flight phase, though the diminutiveness of the female gymnasts, in particular, has been more pronounced in recent times. The following quote highlights the turning point in the 70s. For instance, gymnasts who are shorter and weigh less have greater ratios of strength to weight, greater stability, and reduced moments of inertia (Nauright \& Parrish, 2012).

Good knowledge of anthropological characteristics of the gymnast, who achieve superior results, can be a landmark and a roadmap in which direction should the selection and training process is directed. A variety of sports disciplines determine the development of different anthropological characteristics, and there should be defined standards for each sport. Anthropological characteristics are subject to weather changes, due to which standards have time limits. The practice has shown, and many of the authors in their research, that morphological characteristics of athletes can affect the success in achieving the sports results (Cuk \& Karácsony, 2002; Arkaev \& Suchilin, 2004, Atikovic et al., 2017a,b).

Artistic Gymnastics in the 50s and 60s, the senior competition was dominated by athletes in their mid-to-late twenties. At the time, the "Code of Points" aimed more on artistry and was largely inspired by ballet movement. As a result, more seasoned gymnasts found success in the sport 
by bringing elegance to their routines. Up until 1981, the minimum age for participating in senior competitions was 14 years of age. In 1981, gymnasts were needed to show a minimum of 15 years of age in the calendar year to compete in senior-level competitions. Since 1997, the FIG, the gymnasts had to be at least 16 years old or to be turning 16 within the calendar year in order to take part in the competition as seniors. The regulation for participation at a world championship has been moved up. Today, the limit sits at 18 for MAG and 16 for the WAG (Sands et al., 2012; Grossfeld, 2014; The Fédération Internationale de Gymnastique, 2013, Art. 5.2.pg. 37; Atikovic et al., 2017a,b).

The aim of this study is to determine whether there is a statistically significant difference in the body height $(\mathrm{BH})$ and body weight (BW) between the disciplines of the male and female participants on the Olympic Games from 1996 to the 2016 year.

\section{MATERIAL AND METHOD}

Samples. The sample included male and female the Olympic Athletes from Atlanta 1996, Sydney 2000, Athens 2004, Beijing 2008, London 2012, and Rio de Janeiro 2016.

Variables. The following variables were chosen: $\mathrm{BH}$, body weight $(\mathrm{kg})$; BW, body height $(\mathrm{cm})$. Data was collected through the site: «Sports Reference» https://www.sportsreference.com/olympics/sports/GYM/ and "The Official Website of the Rio 2016 Olympic Games (Rio 2016 Olympic Games, 2016). Data were collected for each athlete, including: sex (male and female).

Statistical Analysis. To evaluate all judge's scores we used Statistical Package for Social Sciences (SPSS, Version 23, IBM, Chicago, Illinois, USA) for Windows to calculate Descriptive Statistics, Levene test confirmed the equality variances, t-test for Equality of Means and Cohen's d effect size. For significance, a 5 percent level of $(p<.05)$ was considered for all statistic parameters. For the total number of years of one's age since the date of birth until the first day of the competition qualifications:

Calculation formula $=$ DATEDIF $\quad$ (days $\quad x$
0.0027397260273973 years $)(1)$

\section{RESULTS}

From the results presented in the (Table I), there are noticeable differences in height of WAG and MAG gymnasts due to the different Olympic Games. We can see how the WAG gymnasts on the OG2012 are, in the average, 155.39 $\mathrm{cm}$ high and $151.76 \mathrm{~cm}$ the shortest on the WAG OG1996 $\mathrm{cm}$. MAG gymnasts on the OG2016 are, in the average, $167.07 \mathrm{~cm}$ high and $166.36 \mathrm{~cm}$ the shortest on the MAG OG1996 cm. From the results, certain differences in the severity of the WAG gymnasts are noticeable, due to the different OG. From the table, we can see how the gymnasts do not change the height of the body over time (Fig. 1).

From the results presented in (Table II), there are noticeable differences in the weight of WAG female gymnasts due to the different time. We can see that WAG gymnasts on OG1996 are, in the average, $42.41 \mathrm{~cm}$ high and on the OG2016 $48.18 \mathrm{~kg}$. The difference of 20 years is also the largest change in body weight in women for 5.77 $\mathrm{kg}$. We can see that the male gymnasts on the OG1996, are on average were the lightest weigh $62.39 \mathrm{~kg}$, and on the OG2016 are, while the gymnasts, on average, weigh 62.93 $\mathrm{kg}$. In men, there is no change in body weight as well as in women over a period of 20 years (Fig. 2).

Conducting the analysis, the gymnasts' height and weight data for each Olympic Games were obtained. Comparing the arithmetic middle and t-test for independent samples, it has been found that there are statistically significant differences in their weight but not in the height. If it comes to the World Championships, the European Championships, or some other competitions, there would most likely be the difference between the disciplines.

Table I. Body height.

\begin{tabular}{|c|c|c|c|c|c|c|c|c|c|c|}
\hline \multirow{2}{*}{\multicolumn{2}{|c|}{$\begin{array}{l}\text { Summer Olympic } \\
\text { Games }\end{array}$}} & \multicolumn{4}{|c|}{$\begin{array}{l}\text { Women's Artistic Gymnastics } \\
\text { (WAG) }\end{array}$} & \multicolumn{5}{|c|}{$\begin{array}{c}\text { Men's Artistic Gymnastics } \\
\text { (MAG) }\end{array}$} \\
\hline & & $\mathrm{M}$ & SD & Skew & Kurt & $\mathrm{N}$ & $\mathrm{M}$ & SD & Skew & Kurt \\
\hline 2016 & 97 & 154.64 & 7.42 & -.65 & .23 & 94 & 167.07 & 6.09 & .23 & .09 \\
\hline 2012 & 96 & 155.39 & 6.14 & -.46 & -.33 & 97 & 167.04 & 5.84 & .23 & .02 \\
\hline 2008 & 98 & 153.85 & 7.51 & -.02 & -.51 & 97 & 166.56 & 5.10 & .72 & 1.29 \\
\hline 2004 & 97 & 153.24 & 6.83 & .14 & -.12 & 98 & 166.79 & 4.48 & .13 & .21 \\
\hline 2000 & 94 & 153.03 & 6.51 & -.25 & -.01 & 97 & 166.67 & 4.83 & .45 & .10 \\
\hline 1996 & 94 & 151.76 & 6.71 & .05 & -.29 & 93 & 166.36 & 4.75 & .30 & .04 \\
\hline
\end{tabular}

Abbreviation: N - Number number of participants; M - Mean; SD - Standard deviation; Skew. - coefficients of skewness; Kurt. - coefficients of kurtosis. 

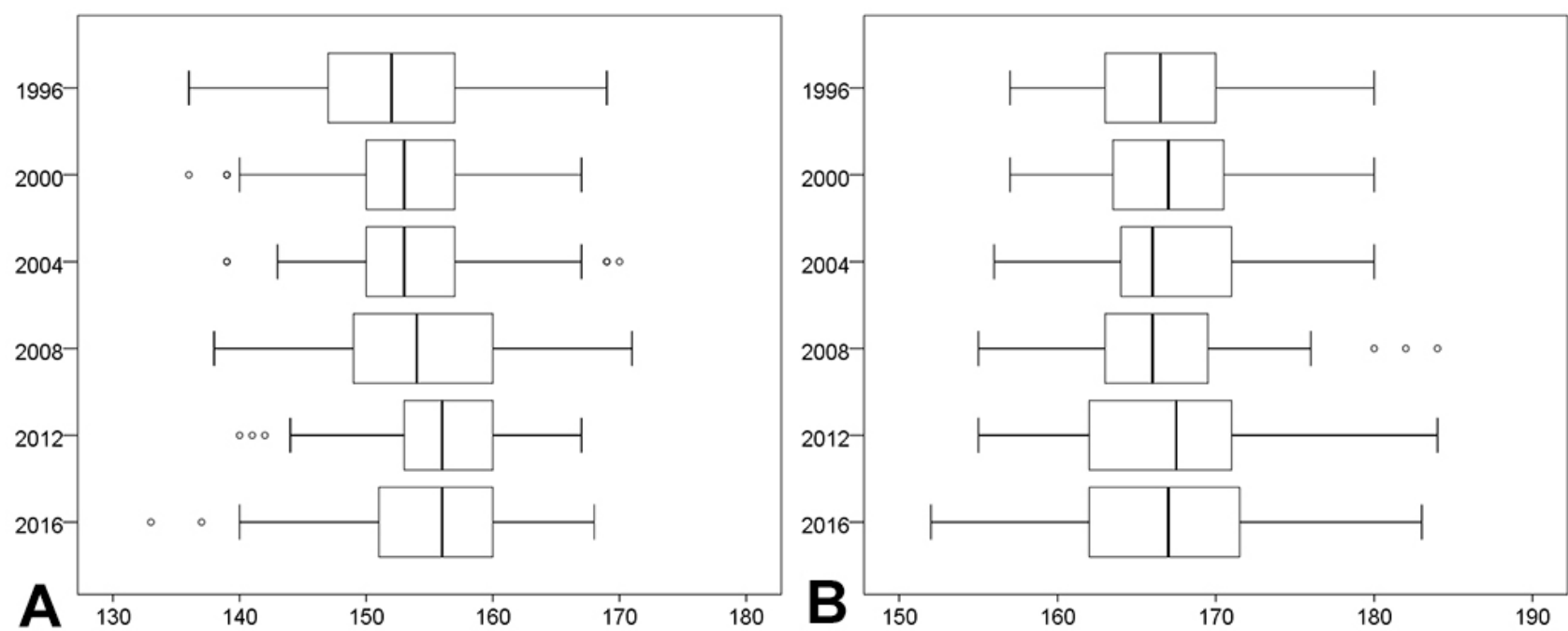

Fig. 1. Body height changes over time. Women's Artistic Gymnastics (WAG) Men's Artistic Gymnastics (MAG)

Table II. Body weight.

\begin{tabular}{|c|c|c|c|c|c|c|c|c|c|c|}
\hline \multirow{2}{*}{$\begin{array}{l}\text { Summer } \\
\text { Olympic } \\
\text { Games }\end{array}$} & \multicolumn{5}{|c|}{$\begin{array}{c}\text { Women's Artistic Gymnastics } \\
\text { (WAG) }\end{array}$} & \multicolumn{5}{|c|}{$\begin{array}{l}\text { Men's Artistic Gymnastics } \\
\text { (MAG) }\end{array}$} \\
\hline & $\mathrm{N}$ & $\mathrm{M}$ & SD & Skew & Kurt & $\mathrm{N}$ & $\mathrm{M}$ & SD & Skew & Kurt \\
\hline 2016 & 97 & 48.18 & 6.70 & -.40 & .14 & 94 & 62.93 & 6.14 & .42 & .42 \\
\hline 2012 & 83 & 47.86 & 6.31 & -.31 & .01 & 91 & 62.97 & 6.08 & .22 & -.48 \\
\hline 2008 & 97 & 45.61 & 6.66 & -.08 & -.81 & 96 & 62.68 & 5.57 & .18 & -.49 \\
\hline 2004 & 97 & 44.90 & 6.70 & .07 & -.58 & 98 & 62.94 & 5.55 & .17 & -.03 \\
\hline 2000 & 94 & 44.44 & 6.46 & -.20 & .12 & 97 & 62.69 & 5.34 & .38 & .53 \\
\hline 1996 & 92 & 42.41 & 5.08 & .30 & -.02 & 93 & 62.39 & 4.98 & .26 & .16 \\
\hline
\end{tabular}

Abbreviation: N - Number number of participants; M - Mean; SD - Standard deviation; Skew. - coefficients of skewness; Kurt. - coefficients of kurtosis.
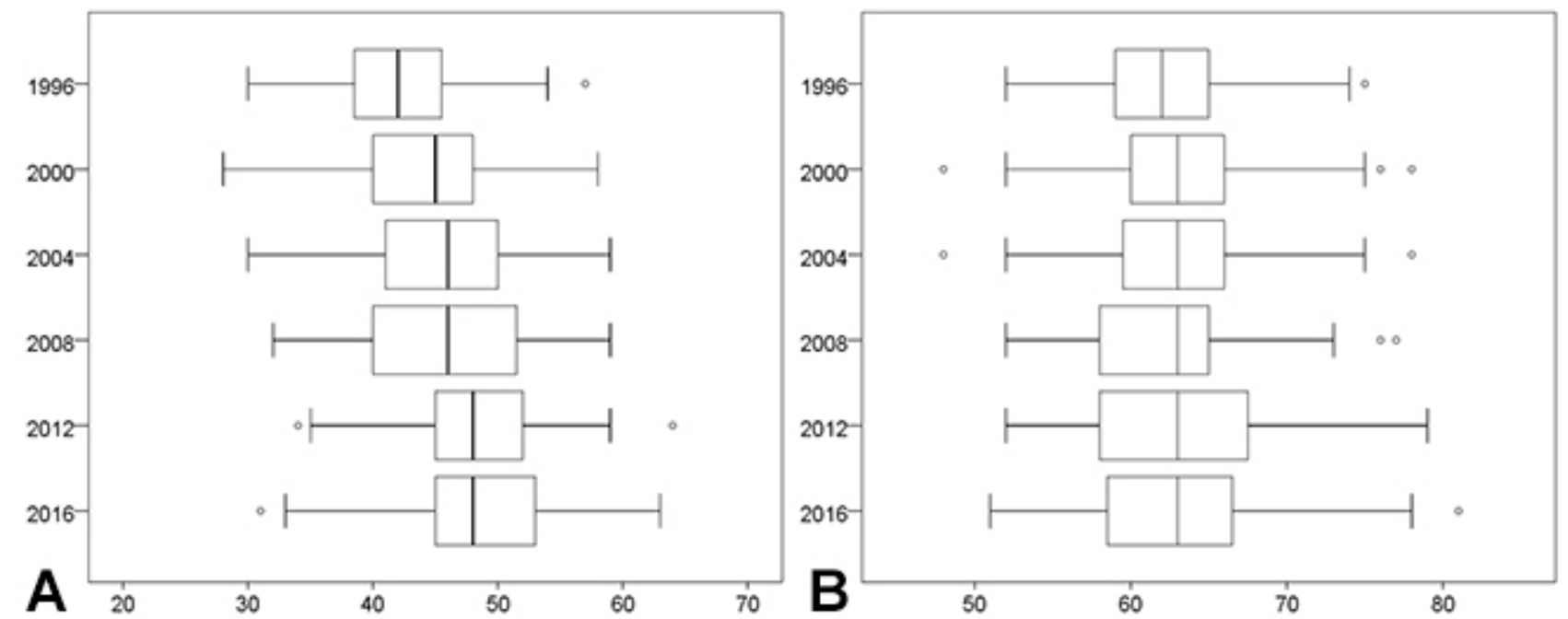

Fig. 2. Body weight changes over time. Women's Artistic Gymnastics (WAG). Men's Artistic Gymnastics (MAG)

The results in (Fig. 3) of independent $t$ test were significant, $\mathrm{t}$ test $(187)=6.64, \mathrm{p}<.000, \mathrm{~d}=.97, \mathrm{r}=.43$, indicating that there are significant differences between WAG body weight $2016(\mathrm{M}=48.18, \mathrm{SD}=6.70, \mathrm{n}=97)$ and the WAG body weight $1996(\mathrm{M}=42.41, \mathrm{SD}=5.08, \mathrm{n}=92)$. The effectsize, $\mathrm{r}$ was small .43. The mean difference is 5.77 


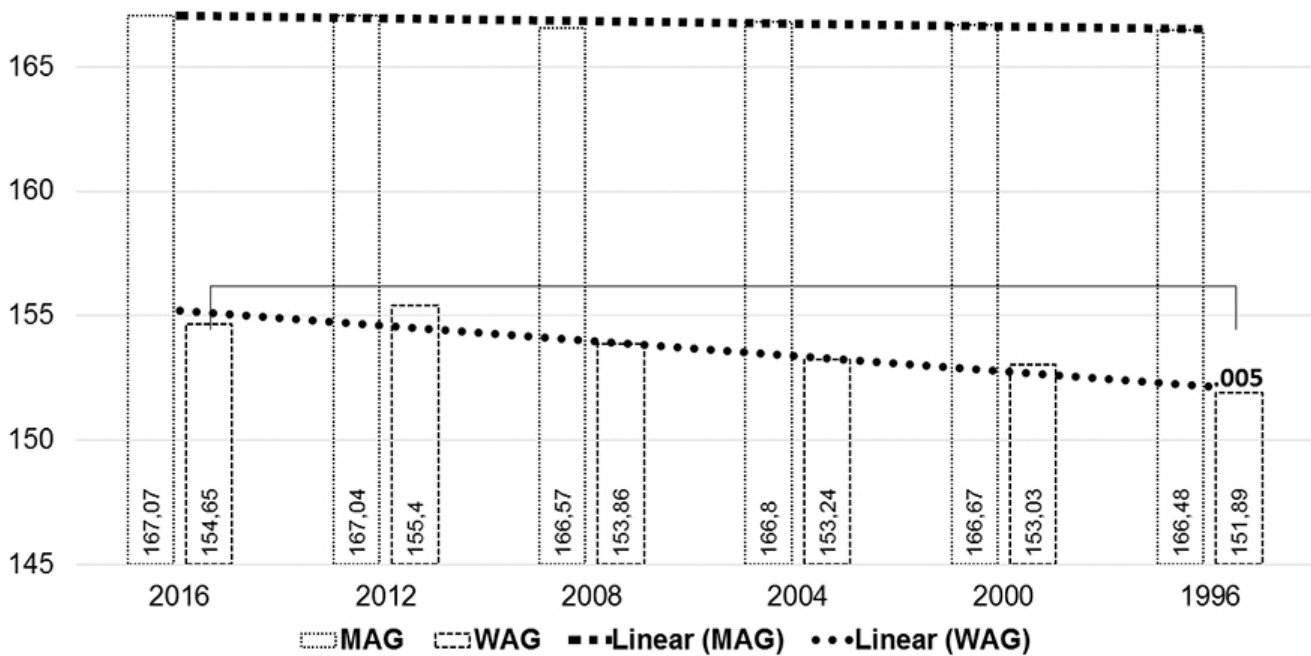

Fig. 3. The differences in body weight over time $(\mathrm{kg})$

$\mathrm{kg}$. The second biggest results of independent $\mathrm{t}$ test were significant, $\mathrm{t}$ test $(189)=3.92, \mathrm{p}<.000, \mathrm{~d}=.57, \mathrm{r}=.27$, indicating that there are significant differences between WAG weight $2016(\mathrm{M}=48.18, \mathrm{SD}=6.70, \mathrm{n}=97)$ and the WAG weight $2000(\mathrm{M}=44.44, \mathrm{SD}=6.46, \mathrm{n}=94)$. The effect size, $r$ was small .27. The mean difference is 3.73 $\mathrm{kg}$. The next one biggest results of independent $\mathrm{t}$ test were significant, $\mathrm{t}$ test $(192)=3.40, \mathrm{p}<.001, \mathrm{~d}=.49, \mathrm{r}=.23$, indicating that there are significant differences between WAG weight $2016(\mathrm{M}=48.18, \mathrm{SD}=6.70, \mathrm{n}=97)$ and the WAG weight $2004(\mathrm{M}=44.90, \mathrm{SD}=6.70, \mathrm{n}=97)$. The effect size, $\mathrm{r}$ was small .23 . The mean difference is $3.27 \mathrm{~kg}$. The last one results of independent $t$ test were significant, $t$ test
$(192)=2.60, \mathrm{p}<.008, \mathrm{~d}=.38, \mathrm{r}=.18$, indicating that there are significant differences between WAG weight $2016(\mathrm{M}=$ $48.18, \mathrm{SD}=6.70, \mathrm{n}=97)$ and the WAG weight $2008(\mathrm{M}=$ 45.61, $\mathrm{SD}=6.66, \mathrm{n}=97)$. The effect size, $\mathrm{r}$ was small .18 . The mean difference is $2.56 \mathrm{~kg}$.

The results in (Fig. 4) of independent $t$ test were significant, $\mathrm{t}$ test $(189)=2.81, \mathrm{p}<.005, \mathrm{~d}=.40, \mathrm{r}=.20$, indicating that there are significant differences between WAG height $2016(\mathrm{M}=154.64, \mathrm{SD}=7.42, \mathrm{n}=97)$ and the WAG height $1996(\mathrm{M}=151.76, \mathrm{SD}=6.71, \mathrm{n}=94)$. The effect size, $\mathrm{r}$ wassmall .20. The mean difference is 2.88 $\mathrm{cm}$.

65

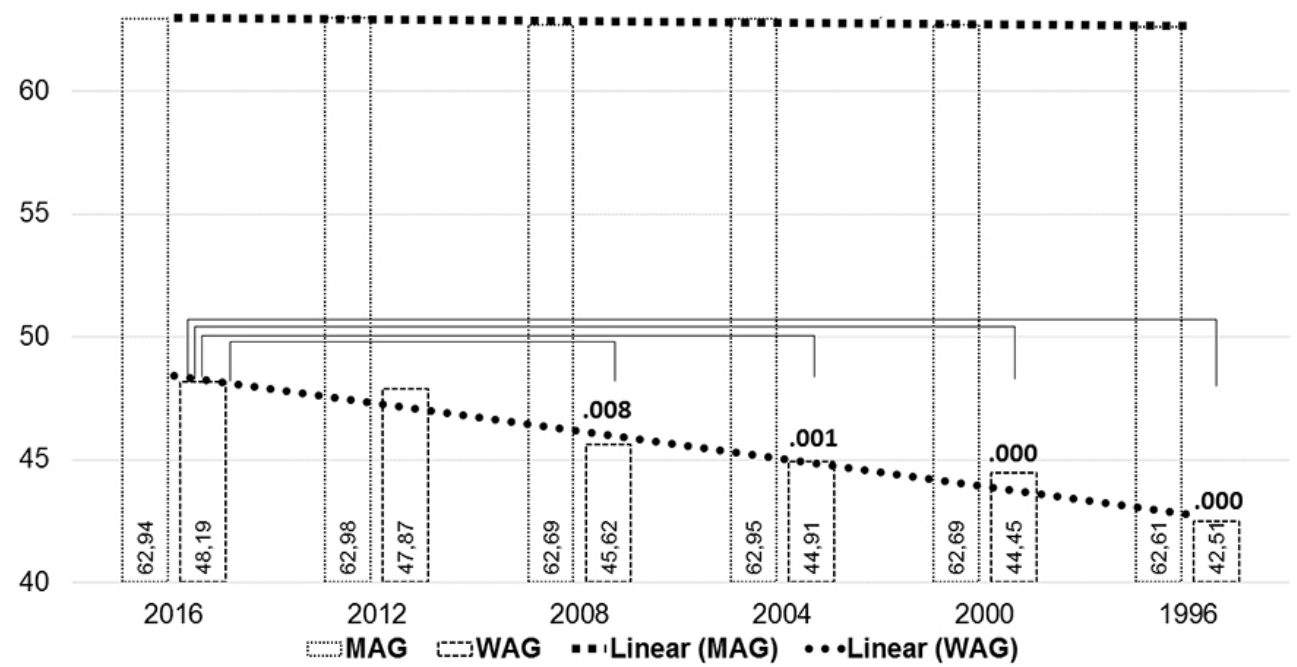

Fig. 4. The differences in body height over time $(\mathrm{cm})$ 
This chronological age (Fig. 5) survey on the time scale from 1996 to 2016 showed the age of top male gymnasts at OG increasing by 2.5 years [OG1996, $(\mathrm{n}=$ $111,22.74 \pm 2.58)$; OG2000, $(\mathrm{n}=97,23.33 \pm 3.19) ;$ OG2004, $(\mathrm{n}=98,24.61 \pm 3.25) ;$ OG2008 ( $=98,25.06 \pm 3.49)$; OG2012, ( $\mathrm{n}=98,24.97 \pm 4.09) ;$ OG2016, $(\mathrm{n}=97$,
$25.24 \pm 3.87)]$. The results show that the top female gymnasts chronological age increased to 4.02 years [OG1996, $(\mathrm{n}=$ 105, 16.77 \pm 2.02$)$; OG2000, $(\mathrm{n}=97,17.65 \pm 2.10)$; OG2004, $(\mathrm{n}=98,18.73 \pm 2.85) ;$ OG2008 ( $\mathrm{n}=97,19.01 \pm 3.03)$; OG2012, $(\mathrm{n}=96,20.43 \pm 3.65) ;$ OG2016, $(\mathrm{n}=98$, 20.79 \pm 4.36$)]$.

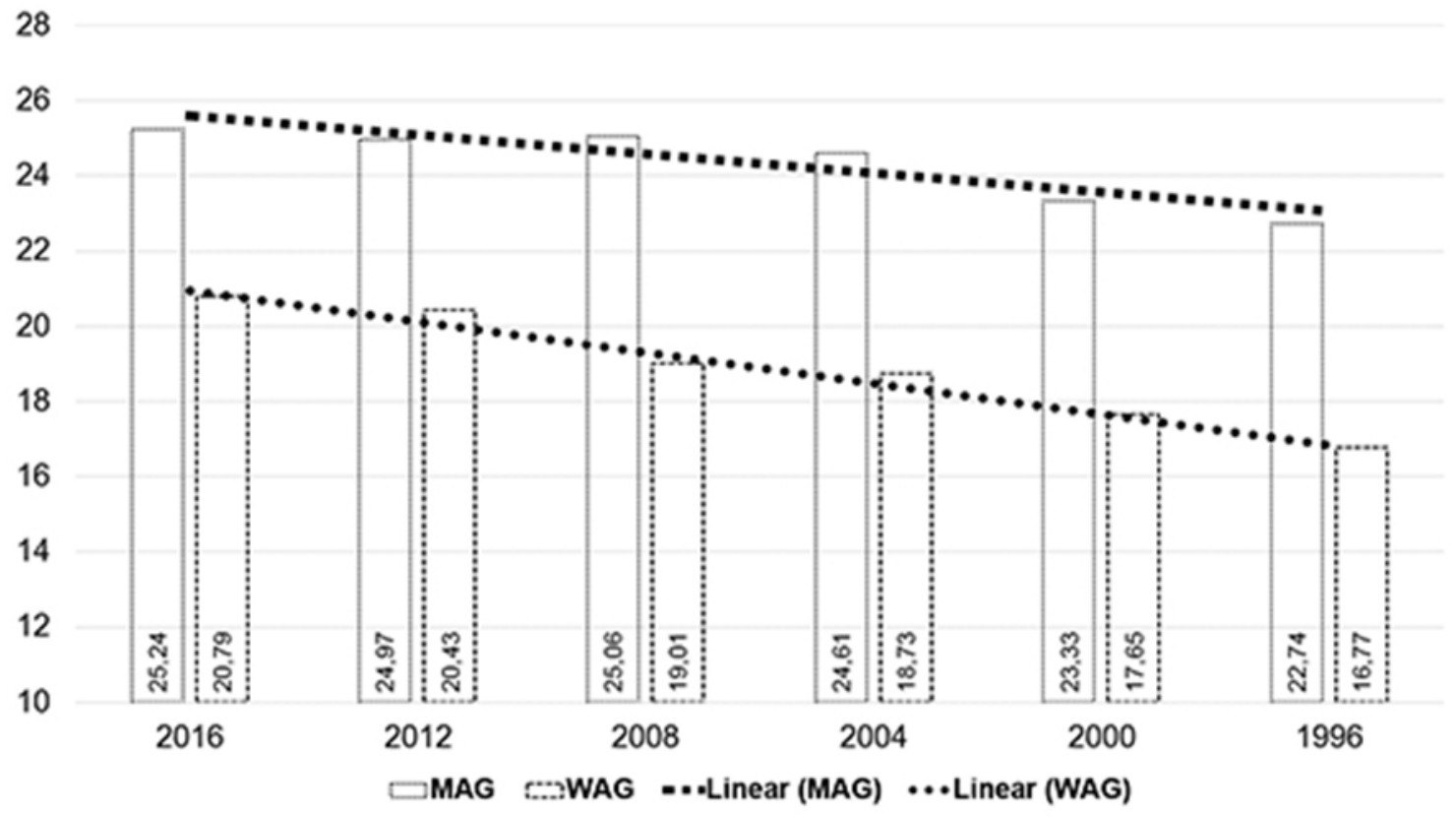

Fig. 5. Chronological age gymnasts at Olympic Games (yrs).

\section{DISCUSSION}

Skrelj, 1934 carried out the characteristics of anthropometric variables for the Sokol gymnasts in [1933; $\mathrm{n}=186$; $\mathrm{BH} \mathrm{M}=169.03, \mathrm{SD}=4.57$; $\mathrm{BW} \mathrm{M}=65.64, \mathrm{SD}=5.91]$. Unfortunately, S`kerlj (1934) did not provide measures of standard age deviation in order to make calculations of statistical differences between then and now. Rozin \& Ceburaev (1981) published results of top gymnasts at [OG1964; BH M=167.7, SD 6.4, BW M=63.6, SD=7.2; 1968 BH $\mathrm{M}=167.9 \mathrm{SD}=6.9, \mathrm{BW} \mathrm{M}=63.9, \mathrm{SD}=6.9 ; 1972 \mathrm{BH}$ $\mathrm{M}=169.1, \mathrm{SD}=5.0, \mathrm{BW} \mathrm{M}=64.2, \mathrm{SD}=4.7 ; 1976 \mathrm{BH}$ $\mathrm{M}=166.7, \mathrm{SD}=5.6, \mathrm{BW} \mathrm{M}=61.1, \mathrm{SD}=5.2 ; 1980 \mathrm{BH}$ $\mathrm{M}=168.2, \mathrm{SD}=4.6, \mathrm{BW} \mathrm{M}=62.8, \mathrm{SD}=5.0]$. In 2000, a World Cup in male Gymnastics was organised in Ljubljana (Slovenia). The meeting was attended by 40 competitors. This competition presented an opportunity for $\mathrm{C}^{`} \mathrm{uk} \&$ Karácsony (2007) to measure physical characteristics of top male gymnasts. Authors presented characteristics of anthropometric variables for contemporary gymnasts in 2000 $[\mathrm{n}=40, \mathrm{BH} \mathrm{M}=168.08, \mathrm{SD}=6.25, \mathrm{~min}=185.50, \max =157.40$ $\mathrm{BW} \mathrm{M}=66.45, \mathrm{SD}=8.15, \min =84.8, \max =51.9]$.
The results of the anthropometric data male gymnast are presented by other authors [OG1928 Amsterdam; n=19, $\mathrm{BH}=166.6, \mathrm{BW}=64.1$, Polish gymnasts (Dybowska \& Dibowski, 1928; Claessens et al., 1991), OG1948 London; $\mathrm{n}=15, \mathrm{BH}=172.7, \mathrm{BW}=74.5$, (Cureton, 1951; Claessens), OG1964 Tokyo; $\mathrm{n}=122, \mathrm{BH}=167.2, \mathrm{BW}=63.3$, (De Garay et al., 1974; Claessens), OG1968 Mexico City; $\mathrm{n}=28$, $\mathrm{BH}=167.4, \mathrm{BW}=65.5$ (De Garay et al.; Claessens), OG1972 Munich; $\mathrm{n}=126, \mathrm{BH}=168.0, \mathrm{BW}=64.1$ (Hirata, 1979), OG1976 Montreal; $\mathrm{n}=101, \mathrm{BH}=168.5, \mathrm{BW}=62.0$, (Hirata, 1979), WC1983 Budapest; $\mathrm{n}=169, \mathrm{BH}=167.8, \mathrm{BW}=62.4$ (Gajodos, 1984), WC1987 Rotterdam; $\mathrm{n}=165, \mathrm{BH}=167.0$, $\mathrm{BW}=63.6$ (Claessens), WC1989 Rotterdam; n=165, $\mathrm{BH}=167.0, \mathrm{BW}=63.6$ (Claessens).

The results of the anthropometric data female gymnast are presented by other authors [OG1964 Tokyo; $\mathrm{n}=102, \mathrm{BH}=157.0, \mathrm{BW}=52.0$, (Hirata, 1966, 1979), OG1968 Mexico City; n=21, BH=156.9, BW=49.8 (De Garay et al.; Claessens), OG1972 Munich; $\mathrm{n}=133, \mathrm{BH}=159.0, \mathrm{BW}=49.5$ (Hirata, 1979), OG1976 Montreal; $\mathrm{n}=93, \mathrm{BH}=159.0$, BW=48.0, (Hirata, 1979), WC1983 Budapest; $\mathrm{n}=161$, $\mathrm{BH}=154.4, \mathrm{BW}=44.0$ (Gajdos` , 1984), WC1987 Rotterdam; 
$\mathrm{n}=165, \mathrm{BH}=167.0, \mathrm{BW}=63.6$ (Claessens), WC1989 Rotterdam; $\mathrm{n}=201, \mathrm{BH}=154.3, \mathrm{BW}=45.6$ (Claessens).

The analysis of the anthropometric characteristics of male gymnasts are also presented in the book «Rings» author's Cuk \& Karácsony the best teams morphologic characteristics at WC in Dortmund, 1994 (Russia: BH $\mathrm{M}=165$, BW $\mathrm{M}=65$; China: $\mathrm{BH} \mathrm{M}=164$, $\mathrm{BW} \mathrm{M}=56$; Belarus: BH $M=166$, BW $M=60$; Ukraine: $B H ~ M=166$, body BW M=61; JPN: BH M=164, BW M=59; GER: BH M=164, BW $\mathrm{M}=59$ ).

By comparing these results with the results obtained through the research are relatively similar (Moznik et al., 2013). Gymnasts in 2007 and 2011 were tall, around 166 $\mathrm{cm}$ and weighed around $62 \mathrm{~kg}$. As for the differences in height and weight by individual disciplines, there's not a lot of difference compared to the measurements carried out in 1933 and 2000, so their research has shown that there is still a difference between the gymnasts in the cut and the bars, which are still taller and heavier than gymnasts on rings and vault. From this research, it is obvious that the top gymnasts are all shorter and weigh less. The trend of the height and weight of the gymnasts is determined by the development of gymnastics in which today dominate strong reflections, large amplitude, a longer stay in the air, fast rotation, and elements with more than one rotation around the transverse and longitudinal axis (The Fédération Internationale de Gymnastique), for which smaller body is much more convenient than the larger one. Also, it has been established that the age of the top gymnasts has increased on average if we compare it with 1933 and the year 2000 (Cuk et al.).

An analysis of all the female US Olympic gymnastics teams by (Sands et al., 2012), found that when using linear correlations height, mass, age, BMI have been declining since 1956. This is the same as the result below, in this analysis of just the Olympic champions. However, against this trend, second-order polynomial curve fits indicated that in the last four OG the gymnastics have been getting heavy. The best US Olympic team finishes were accomplished when the teams were not the smallest, lightest, or leanest but greater than the lowest recorded values. The minimum age rule modifications may have played a role in the athlete size changes along with a shift from the near dominance of the former communist Eastern Bloc.

A number of athletes competing in each sport OG2012 and as a percentage of the total. Artistic gymnastics $\mathrm{n}=198$ or $1.8 \%$ all athletes $(\mathrm{n}=10881)$ at OG2012, (The Guardian, 2016). The average heights of the Olympic allaround gymnastics champions have generally decreased in the data shown from 1956 until 2012. The decrease in height is more pronounced for women than men. The BW of the Olympic all-around gymnastics winners has generally decreased in the data shown from 1956 until 2012, in line with changes in height. The decrease in weight is more pronounced for women than men (Topend Sports, 2016).

Dr. Kevin Thomson, wrote about the physical qualities of gymnasts for the BBC, noted that «being small» helps with rotational skills (for example, somersaults with multiple rotations). For the same reason, gymnasts also tend to have short arms and legs (Thomson, 2016). Dr. Malina, suggested most gymnasts are short because they have short parents, rather than because over-training stunted their growth. However, the fact that gymnasts are small can't all be credited to self-selection (Tanner et al., 1983; Moss, 2016). A study published (Bass et al., 2000) found that, while the sport does draw women who are short and have delayed bone age (means that your skeletal maturation is lagging behind your actual age), gymnastics training can have some impact on growth.

The results (Atikovic et al., 2017a,b) not showed significant differences between six apparatus in men's artistic gymnastics and four in women's artistic gymnastics in body height and weight. In the OG 2016, women are on average shorter than men for $12.34 \mathrm{~cm}$ and weightless for $14.75 \mathrm{~kg}$. Correlations between body height and weight amounts to (MAG: $\mathrm{r}=.71 ; \mathrm{p}<0.01$ ) and (WAG: $\mathrm{r}=.75 ; \mathrm{p}<0.01$ ). Atikovic' et al. (2017a,b) show also in the last 15 years, there has been identified a linear and second-order polynomial-regression increase in the age structure of participants in MAG and WAG in the largest world competitions. In the analyzed period of time, MAG and WAG age of gymnasts increased. The male gymnasts from 2003 to 2016 are on average older for 2.3 years and female gymnasts for 3.3 years. In the upcoming period, we do expect (with apparatus specialization) that age will rise. Changes in the General Rules and Code of Points by the Fédération Internationale de Gymnastique after 1997 years the trend is a significant change in the Olympic Games for WAG.

\section{CONCLUSIONS}

Defining the influence of morphological characteristics to the final performance in particular gym activities is extremely important. The reasons for this claim can be presented through the following points:

- on the basis of accurately established importance of some morphological features of the final result, one can safely approach to the selection and orientation. 
- a single morphological characteristic that has a high impact on the final result in a discipline of gymnastics in the overall training scratch up should be more represented from other elements that are not so much connected with the final result. - on the basis of the data of the specific importance of some morphological characteristics, it can be a better approach to modeling gymnastics training.

On the basis of what was presented in the work, the importance of the permanent identification of morphological characteristics in sports gymnastics is clear, because it is only this way that can affect their sport development, and thus to achieving outstanding results such as the Olympic Games where the best athletes from all around the world come.

ATIKOVIC, A. Características antropométricas de gimnastas artísticos olímpicos femeninos y masculinos de 1996 a 2016. Int. J. Morphol., 38(4):990-996, 2020.

RESUMEN: El éxito en la gimnasia artística depende de las características morfológicas de los atletas, algunas de las cuales son la altura y el peso del cuerpo. El objetivo de este estudio fue determinar si existe una diferencia estadísticamente significativa entre la altura y el peso corporal en los participantes masculinos y femeninos en los Juegos Olímpicos de 1996 a 2016. Se eligieron las siguientes variables: peso corporal (kg), altura corporal $(\mathrm{cm})$. Los resultados mostraron diferencias significativas entre la gimnasia artística femenina en el peso corporal y la altura durante un período de 20 años. En la gimnasia artística masculina no se observó diferencia. Esta investigación es importante para establecer parámetros comparativos en el proceso de selección y la especialización deportiva con respecto a las características morfológicas, de acuerdo a los eventos en que participan gimnastas de nivel de élite.

PALABRAS CLAVE: Gimnasia artística; Juegos olímpicos; Atletas de élite; Características antropológicas.

\section{REFERENCES}

Arkaev, L. I. \& Suchilin, N. G. How to Create Champions. Oxford, Meyer \& Meyer Sport, 2004

Atikovic, A.; Delas Kalinski, S.; Nozinovic Mujanovic, A. \& Kremnick, J. Comparative analysis of morphological characteristics in men's and women's artistic gymnastics in the Olympic Games 2016 in Rio de Janeiro, Brazil. Slovak J. Sport Sci., 2(2):61-9, $2017 \mathrm{~b}$.

Atikovic, A.; Delas, K. S. \& Cuk, I. Age trends in artistic gymnastic across World Championships and the Olympic Games from 2003 to 2016. Sci. Gymn. J., 9(3):251-63, 2017a

Bass, S.; Bradney, M.; Pearce, G.; Hendrich, E.; Inge, K.; Stuckey, S.; Lo, S. K. \& Seeman, E. Short stature and delayed puberty in gymnasts: influence of selection bias on leg length and the duration of training on trunk length. $J$. Pediatr., 136(2):149-55, 2000.

Claessens, A. L.; Veer, F. M.; Stijnen, V.; Lefevre, J.; Maes. H., Steens, G.; \& Beunen, G. Anthropometric characteristics of outstanding male and female gymnasts. J. Sports Sci., 9(1):53-74, 1991.
Cureton, T. K. Physical Fitness of Champion Athletes. Urbana, The University of Illinois Press, 1951.

Cuk, I. \& Karácsony, I. Rings. Methods, Ideas, Curiosities, History. Norman (OK), Paul Ziert \& Associates, 2002.

Cuk, I.; Korencic, T.; Tomazo-Ravnik, T.; Pecek, M.; Bucar, M. \& Hraski, Z. Differencies in morphologic characteristics between top level gymnasts of year 1933 and 2000. Coll. Antropol., 31(2):613-9, 2007.

De Garay A. L.; Levine, L. \& Carter, J. E. L. Genetic and Anthropological Studies of Olympic Athletes. New York, Academic Press. 1974.

Dybowska, J. \& Dibowski, W. Anthropologische Untersuchungen an Teilnehmern der Wettkämpfe de IX. Olympiade in Amsterdam 1928. In: Buytendijk, F. J. J. (Ed.). Ergebnisse der Sportärzlichen Untersuchungen be den IX Olympischen Spielen. Berlin, Verlag von Julius Springer, 1928.

Gajdos, A. Alter, Körpergröße und gewicht bei Kunstturnern und Kunstturnerinnen der W.M. 1983 in Budapest. Leistugssport, 14:17-8, 1984.

Hirata, K. Physique and age of Tokyo Olympic champions. J. Sport Med. Phys. Fit., 6:207-22, 1966.

Hirata, K. Selection of Olympic Champions. Vol. II. Tokyo, Chukyo University, 1979.

Moss, G. Why Are Gymnasts So Short? Whether Gymnastics Stunts Growth, Explained. Bustle, 2016. Available from: http://www.bustle.com/articles/ 177666-why-are-gymnasts-so-short-whether-gymnastics-stunts-growthexplained

Moznik, M.; Hraski, Z. \& Hraski, M. Height, weight and age of male top-level gymnasts in year 2007 and 2011. Croat. Sports Med. J., 28(1):14-23, 2013.

Nauright, J. \& Parrish, C. Sports Around the World. History, Culture and Practice. Santa Barbara, ABC-CLIO, 2012.

Rio 2016 Olympic Games. Gymnastics Artistic. The Official Website of the Rio 2016 Olympic Games, 2016. Available from: https://www.olympic.org/rio2016/gymnastics-artistic

Rozin, E. J. \& Ceburaev, V. S. Vozrastnie i rosto-vesovie pokazateli ucastnikov XXII olimpijskih igr. Gimnastika, 1:35-9, 1981.

Sands, W. A.; Slater, C.; McNeal, J. R.; Murray, S. R. \& Stone, M. H. Historical trends in the size of US Olympic female artistic gymnasts. Int. J. Sports Physiol. Perform., 7(4):350-6, 2012.

Skerlj, B. Sokolski vestnik. SOKO, 4:211-7, 1934

Tanner, J. M.; Whitehouse, R. H.; Cameron, N.; Marshall, W. A.; Healy, M. J. R. \& Goldstein, H. Assessment of Skeletal Maturity and Prediction of Adult Height (TW2 Method). $2^{\text {nd }}$ ed. London, Academic Press, 1983.

The Fédération Internationale de Gymnastique (FIG). Code of Points for Men's Artistic Gymnastics. Moutier, The Fédération Internationale De Gymnastique, 2013.

The Guardian. Could you be an athlete? Olympics 2012 by age, weight and height. The Guardian, 2012. Available from: https://www.theguardian.com/sport/ datablog/2012/aug/07/olympics-2012-athletes-age-weight-height\#age

Thomson, K. Are you a born gymnast? Academy, 2016. Available from: http:// news.bbc.co.uk/sportacademy/hi/sa/newsid_3577000/3577460.stm

Topend Sports. Anthropometric Measurements of Olympic Gymnastics Champions. Topend Sports, The Sport \& Science Resource, 2016. Available from: http://www.topendsports.com/events/summer/science/gymnastics-allround.htm

Corresponding author:

Almir Atikovic, Ph.D.

Faculty of Physical Education and Sport

University of Tuzla

2. Oktobra 1

75000 Tuzla

BOSNIAAND HERZEGOVINA

Email: almir.atikovic@untz.ba

Received: 25-11-2019

Accepted: 12-02-2020 